\title{
PENGARUH PENERAPAN METODE PEMBELAJARAN LATTICE TERHADAP HASIL BELAJAR MATEMATIKA PESERTA DIDIK
}

\author{
Reski Ayu ${ }^{1}$, Lisa Aditya Dwiwansyah Musa ${ }^{1 *}$ \\ ${ }^{1}$ IAIN Palopo \\ Corresponding Author: lisa_aditya_dwiwansyah_musa@iainpalopo.ac.id*
}

\begin{abstract}
This study aimed to determine the effect of lattice learning methods on mathematics learning outcomes on the integer multiplication operation for the grade VII students of SMPN 2 Bua. This is a preexperimental research design that uses a one-group pretest-posttest research design type. The instrument used a description test consist of 3 questions. The samples were students of class VII A of SMPN 2 Bua. The analysis result of the two-tailed curve, $\mathrm{H}$ a was accepted, and Ho was rejected. The conclusion was a significant influence on the lattice learning method on mathematics learning outcomes in the integer for grade VII students of SMPN 2 Bua. So, a successful student not only by learning theory but also by the right learning methods. The results of this study will be able to help teachers to improve student learning outcomes.
\end{abstract}

Keywords: Lattice learning method; Learning outcomes; Integer multiplication

How to cite: Ayu, R., Musa, L. A. D. (2019). Pengaruh Penerapan Metode Pembelajaran Lattice Terhadap Hasil Belajar Matematika Peserta Didik. JRPM (Jurnal Review Pembelajaran Matematika), 5(1), 30-39.

\section{PENDAHULUAN}

Pada hakikatnya matematika adalah ilmu yang bersifat abstrak dan pola pikirnya deduktif. Hal ini sejalan dengan pendapat Wardhani (2010), bahwa matematika merupakan buah pikiran manusia yang kebenarannya bersifat umum atau deduktif dan tidak tergantung dengan metode ilmiah yang memuat proses induktif. Kebenaran matematika bersifat koheren, artinya didasarkan pada kebenaran-kebenaran yang telah diterima sebelumnya. Matematika perlu diberikan kepada peserta didik untuk membekali mereka agar memiliki kemampuan berpikir logis, analitis, sistematis, kritis dan kreatif. Matematika mempunyai peranan yang penting dalam proses berpikir peserta didik, terutama dalam pembentukkan kemampuan menganalisis, melakukan evaluasi hingga memecahkan masalah. Salah satu kemampuan yang harus dikuasai peserta didik dengan belajar matematika adalah memahami konsep yang artinya peserta didik harus dapat menjelaskan keterkaitan antar konsep dan mengaplikasikan konsep atau algoritma secara tepat dalam menyelesaikan soal matematika terutama perhitungan yang berkaitan dengan materi bilangan bulat.

Bilangan bulat merupakan salah satu materi yang diajarkan dalam pembelajaran matematika pada tingkat sekolah dasar dan menengah pertama. Setyaningsih menjelaskan bahwa konsep bilangan bulat yang dipelajari di tingkat sekolah menengah pertama meliputi 
bilangan bulat negatif, nol, dan bilangan bulat positif atau gabungan bilangan cacah dan bilangan bulat negatif (Yudhautama \& Ratu, 2019). Bilangan cacah itu sendiri adalah bilangan nol dan bilangan bulat positif.

Berdasarkan hasil observasi dan wawancara yang dilakukan peneliti pada tanggal 17 Juni 2019 pembelajaran matematika termasuk mata pelajaran yang dianggap sulit oleh peserta didik kelas VII SMPN 2 Bua. Hal ini disebabkan matematika adalah mata pelajaran yang bersifat abstrak sehingga sulit dipahami peserta didik, terlebih jika dihadapkan pada operasi hitung perkalian atau pembagian dalam jumlah angka yang cukup besar dan cara penyelesaian yang panjang. Selain itu, cara mengajar guru yang belum menggunakan media pembelajaran yang bisa menarik perhatian peserta didik sehingga mengakibatkan kebosanan dan kebingungan mencari penyelesaian dengan cara yang cepat dan tepat. Guru mata pelajaran matematika kelas VII SMPN 2 Bua mengeluh tentang banyaknya peserta didik yang tidak bisa operasi perkalian bilangan bulat, bahkan perkalian bilangan asli satuan mereka tidak hafal. Sehingga hal ini menghambat dalam proses kegiatan belajar mengajar matematika. Hal ini berdampak pada hasil belajar peserta didik pada mata pelajaran matematika masih rendah.

Uskono, Djong, dan Leton (2019) menyatakan bahwa faktor yang mengakibatkan hasil belajar peserta didik berada di bawah rata-rata antara lain faktor sekolah, faktor peserta didik, faktor pembelajaran, materi matematika itu sendiri, dan berbagai faktor lainnya. Belum maksimalnya hasil belajar matematika tidak terlepas dari proses pembelajaran matematika yang dilaksanakan, untuk itu perlu diciptakan sebuah kondisi belajar yang menyenangkan peserta didik. Dengan kondisi yang menyenangkan peserta didik akan lebih termotivasi dalam belajar, memiliki minat yang tinggi dalam belajar, dan memiliki sikap matematika yang baik dan pada akhirnya dapat meningkatkan hasil belajar peserta didik. Menurut Musa (2016), hasil belajar adalah tingkat penguasaan yang dicapai peserta didik dengan menggunakan alat ukur berupa tes hasil belajar yang disusun secara terencana, baik tes tertulis, tes lisan, maupun tes perbuatan. Sehingga, peneliti akan membuat tes tertulis untuk mengukur penguasaan peserta didik.

Salah satu metode pembelajaran yang dapat digunakan mengatasi kesulitan peserta didik mempelajari konsep dan operasi bilangan bulat adalah metode pembelajaran Lattice. Seperti yang dikemukakan oleh Mulyanto, Handoyo, dan Santoso (2019), yang menyatakan bahwa metode pembelajaran Lattice merupakan metode pembelajaran yang digunakan untuk mengajarkan operasi dasar matematika. Sejalan pula dengan pendapat Kusumawati 
(2010) yang menyatakan bahwa pembelajaran dengan metode kisi-kisi (metode pembelajaran Lattice) ini menjadi alternatif pola pengajaran baru yang lebih efektif dan menyenangkan karena pembelajaran ini efektif untuk peserta didik.

Handojo (2004) menjelaskan bahwa metode pembelajaran Lattice adalah metode pembelajaran yang menggunakan media kotak perkalian yang membutuhkan permainan memori dan latihan serta harus hafal perkalian $9 \times 9$. Metode ini memberikan kemudahan menghitung suatu perkalian dengan cara membuat kotak sehingga peserta didik memiliki ketangkasan dan keterampilan berhitung perkalian. Metode pembelajaran Lattice atau kotak perkalian ini terbukti sangat efektif untuk digunakan dalam menghitung perkalian yang hasilnya lebih dari dua digit, karena media kotak perkalian sangat mudah untuk dipahami bagi peserta didik yang kesulitan belajar operasi hitung perkalian pada pembelajaran matematika. Metode perkalian Lattice sangat berbeda dengan metode perkalian bersusun, dimana nilai puluhan dan satuan sudah ditempatkan dalam kotak tertentu sehingga mengurangi tingkat kesalahan peserta didik dalam operasi perkalian.

Seperti halnya metode pembelajaran lain metode pembelajaran Lattice ini juga memiliki kelebihan dan kekurangan. Adapun kelebihan dari metode Lattice adalah: 1) perhatian peserta didik dapat dipusatkan dan titik berat yang dianggap penting oleh guru dapat diamati, 2) perhatian peserta didik akan lebih terpusat pada apa yang didemonstrasikan, jadi proses pembelajaran akan lebih terarah dan akan mengurangi perhatian peserta didik kepada masalah lain karena melihat hal yang baru, 3) dapat merangsang peserta didik untuk lebih aktif dalam mengikuti proses belajar, 4) dapat menambah pengalaman peserta didik, 5) bisa membantu peserta didik mengingat lebih lama tentang materi yang disampaikan, 6) dapat mengurangi kesalahpahaman karena pengajaran lebih jelas dan konkrit, dan 7) dapat menjawab semua masalah yang timbul di dalam pikiran setiap peserta didik karena ikut serta berperan secara langsung. Sedangkan kekurangannya yaitu:1) memerlukan waktu yang lama, 2) tidak semua peserta didik paham dengan metode Lattice karena masih dianggap baru (Zubaidah, Margiati, \& Kresnadi, 2015).

Banyak penelitian terdahulu yang telah menerapkan metode Lattice ini dalam pembelajaran dan terbukti dapat meningkatkan hasil belajar matematika peserta didik dalam materi bilangan bulat. Seperti penelitian yang dilakukan oleh Zubaidah et al. (2015) yang memperoleh simpulan terjadi peningkatan hasil belajar peserta didik dengan menggunakan metode Lattice. Begitu juga dengan penelitian yang dilakukan oleh Hapriani (2018) yang menunjukkan bahwa metode pembelajaran Lattice berpengaruh terhadap hasil belajar 
peserta didik. Salah satu penelitian terbaru yang dilakukan oleh Solikin, Cipta, dan Anugraini (2019) juga menyatakan bahwa penggunaan metode pembelajaran Lattice dapat mengatasi rendahnya kemampuan berhitung operasi perkalian. Rata-rata penelitian terdahulu diterapkan untuk peserta didik sekolah dasar, akan tetapi dalam penelitian ini yang menjadi sampel adalah peserta didik sekolah menengah pertama. Karena berdasarkan observasi yang peneliti telah lakukan, masih banyak peserta didik SMP yang terkendala dalam operasi perhitungan terutama perkalian.

Berdasarkan uraian di atas, maka tujuan dari penelitian ini adalah untuk mengetahui: 1) hasil belajar matematika peserta didik kelas VII SMPN 2 Bua sebelum diterapkan metode pembelajaran Lattice, 2) hasil belajar matematika peserta didik kelas VII SMPN 2 Bua setelah diterapkan metode pembelajaran Lattice, serta 3) pengaruh penerapan metode pembelajaran Lattice terhadap hasil belajar matematika pada materi operasi perkalian bilangan bulat peserta didik kelas VII SMPN 2 Bua.

\section{METODE PENELITIAN}

Jenis penelitian ini adalah pre experimental designs dengan bentuk penelitian one group pretest posttest design. Desain penelitian yang digunakan dapat digambarkan sebagai berikut:

Tabel 1. Desain Penelitian

\begin{tabular}{lcc}
\hline \multicolumn{1}{c}{ Pretest } & Treatment & Posttest \\
\hline $\mathrm{O}_{1}$ & $\times$ & $\mathrm{O}_{2}$ \\
\hline \multicolumn{3}{c}{ Sumber: Sugiyono (2013) } \\
Keterangan: \\
$\mathrm{O}_{1}=$ Tes Awal sebelum perlakuan diberikan \\
$\mathrm{O}_{2}=$ Tes Akhir setelah perlakuan diberikan \\
$\times=$ Perlakuan dengan menerapkan metode pembelajaran Lattice
\end{tabular}

Dengan demikian hasil perlakuan dapat diketahui lebih akurat, karena dapat membandingkan dengan keadaan sebelum diberi perlakuan. Variabel bebas adalah penerapan metode Lattice sedangkan variabel terikat adalah hasil belajar matematika. Pengaruh yang dimaksud pada penelitian ini adalah suatu akibat yang timbul dari penerapan metode pembelajaran Lattice terhadap hasil belajar. Metode Lattice yang dimaksud dalam penelitian ini adalah metode perkalian yang menggunakan kisi-kisi untuk mengalikan dua angka multi digit yang disajikan dalam bentuk tabel yang memuat hasil perkalian. Hasil belajar matematika yang dimaksud yaitu nilai pretest yang diperoleh peserta didik sebelum perlakuan dan nilai posttest yang diperoleh peserta didik setelah mengikuti proses pembelajaran dengan menggunakan metode pembelajaran Lattice. Jadi, penelitian ini 
difokuskan untuk melihat pengaruh metode pembelajaran Lattice terhadap hasil belajar matematika pada materi operasi perkalian bilangan bulat peserta didik kelas VII SMP Negeri 2 Bua. Populasi dalam penelitian ini adalah seluruh peserta didik kelas VII SMP Negeri 2 Bua yang berjumlah 143 peserta didik. Teknik sampling yang digunakan dalam penelitian ini adalah probability sampling dengan jenis teknik simple random sampling. Sugiyono (2013) menjelaskan bahwa simple random sampling adalah pengambilan sampel yang dilakukan secara acak tanpa memperhatikan strata yang ada dalam populasi itu, sehingga sampel yang terpilih adalah peserta didik kelas VII A berjumlah 25 peserta didik. Teknik pengumpulan data yang digunakan yaitu tes hasil belajar dalam hal ini pretest dan posttest.

Pretest dan posttest menggunakan materi yang sama yaitu perkalian bilangan bulat yang diberikan oleh guru dengan waktu pengerjaan yang sama pula. Untuk mengetahui ada atau tidaknya pengaruh maka digunakan hasil uji-t dengan melihat signifikansi perbedaan hasil tes peserta didik sebelum dan sesudah diberi perlakuan. Hipotesis tindakan pada penelitian ini adalah ada pengaruh metode pembelajaran lattice terhadap hasil belajar matematika pada materi perkalian bilangan bulat peserta didik kelas VII SMPN 2 Bua. Untuk keperluan pengujian statistik, maka hipotesis dirumuskan sebagai berikut:

$$
H_{0}: \mu_{1}=\mu_{2} \text { lawan } H_{1}: \mu_{1} \neq \mu_{2}
$$

Keterangan:

$H_{0}$ : Tidak ada pengaruh metode pembelajaran Lattice terhadap hasil belajar matematika peserta didik kelas VII SMPN 2 Bua.

$H_{1}$ : Ada pengaruh metode pembelajaran Lattice terhadap hasil belajar matematika peserta didik kelas VII SMPN 2 Bua.

$\mu_{1}$ : Rata-rata hasil belajar matematika peserta didik sebelum adanya perlakuan.

$\mu_{2}$ : Rata-rata hasil belajar matematika peserta didik setelah adanya perlakuan.

\section{HASIL DAN PEMBAHASAN}

Dalam penelitian ini, peneliti menggunakan validasi isi instrumen dimana pembuktian validitas isi diperoleh dengan kesepakatan para ahli (expert judgements), yaitu orang yang memiliki kepakaran di bidang yang sesuai dengan instrumen untuk penelitian. Pada penelitian ini hasil validitas instrumen menunjukkan instrumen dapat digunakan dengan revisi kecil. Untuk reliabilitas yang digunakan dalam penelitian ini adalah Alpha Cronbach. Reliabilitas instrumen dapat dihitung dengan bantuan IBM SPSS Statictics 22 menggunakan reliability analysis. Diperoleh hasil berikut: 


\section{Reliabilitas Pretest}

Tabel 2. Case Processing Summary of Pretest

\begin{tabular}{llrr}
\hline & & & \\
\hline \multirow{3}{*}{ Cases } & Valid & 25 & 100.0 \\
& Excluded $^{\mathrm{a}}$ & 0 & .0 \\
& Total & 25 & 100.0 \\
\hline
\end{tabular}

a. Listwise deletion based on all variables in the procedure

Berdasarkan tabel 2 di atas, diperoleh informasi tentang jumlah sampel atau responden $(\mathrm{N})$ sebanyak 25 Orang.

Tabel 3. Reliability Statistics of Pretest

\begin{tabular}{lr}
\hline $\begin{array}{l}\text { Cronbach's } \\
\text { Alpha }\end{array}$ & N of Items \\
\hline & .610 \\
\hline
\end{tabular}

Berdasarkan Tabel 3 di atas, ada 3 item atau butir pertanyaan dengan nilai Cronbach's Alpha 0,610. Berdasarkan kriteria koefisien reliabilitas menurut Subana dan Sudrajat (2005) nilai Cronbach's Alpha yang terletak pada interval 0,6 $<r_{11}<0,8$ termasuk dalam kriteria reliabilitas tinggi. Hal ini menunjukkan bahwa instrumen pretest dapat dipercaya untuk digunakan pada penelitian.

\section{Reliabilitas Posttest}

Tabel 4. Case Processing Summary of Posttest

\begin{tabular}{llrr}
\multicolumn{5}{c}{ Tabel 4. Case Processing Summary of Posttest } \\
\hline \multicolumn{1}{c}{ Cases } & V & $\%$ & \\
& Exclid $^{*}$ & 25 & 100.0 \\
& Total $^{\mathrm{a}}$ & 0 & .0 \\
& 25 & 100.0 \\
\hline
\end{tabular}

a. Listwise deletion based on all variables in the procedure

Berdasarkan tabel 4 di atas, diperoleh informasi tentang jumlah sampel atau responden $(\mathrm{N})$ sebanyak 25 Orang.

Tabel 5. Reliability Statistics of Posttest

\begin{tabular}{lr}
\hline $\begin{array}{l}\text { Cronbach's } \\
\text { Alpha }\end{array}$ & N of Items \\
\hline & \\
\hline
\end{tabular}

Berdasarkan tabel 5 di atas, ada 3 item atau butir pertanyaan dengan nilai Cronbach's Alpha 0,710. Berdasarkan kriteria koefisien reliabilitas menurut Subana dan Sudrajat (2005) nilai Cronbach's Alpha yang terletak pada interval 0,6 $<r_{11}<0,8$ termasuk dalam kriteria reliabilitas tinggi. Ini menunjukkan bahwa instrumen posttest dapat dipercaya untuk digunakan pada penelitian. Sebelum melakukan analisis uji-t terlebih dahulu peneliti melakukan penyajian data dan melakukan uji persyaratan data yaitu uji normalitas data dan uji homogenitas data.

\section{Analisis Statistik Deskriptif}

Perhitungan statistik deskriptif dengan menggunakan program SPSS, diperoleh data 
sebagai berikut:

Tabel 6. Statistics Descriptif

\begin{tabular}{|c|c|c|c|}
\hline & & Pretest & Posttest \\
\hline \multirow{2}{*}{$N$} & Valid & 25 & 25 \\
\hline & Missing & 0 & 0 \\
\hline \multicolumn{2}{|c|}{ Mean } & 3,96 & 7,16 \\
\hline \multicolumn{2}{|c|}{ Median } & 4,00 & 7,00 \\
\hline \multicolumn{2}{|c|}{ Mode } & $5^{\mathrm{a}}$ & 8 \\
\hline \multicolumn{2}{|c|}{ Std. Deviation } & 1,791 & 1,625 \\
\hline \multicolumn{2}{|c|}{ Variance } & 3,207 & 2,640 \\
\hline \multicolumn{2}{|c|}{ Minimum } & 1 & 4 \\
\hline \multicolumn{2}{|c|}{ Maximum } & 7 & 10 \\
\hline
\end{tabular}

Berdasarkan tabel 6 di atas, diperoleh nilai rata-rata pretest untuk 25 responden yaitu 3,96 dengan standar deviasi 1,791. Sedangkan nilai rata-rata posttest untuk 25 responden yaitu 7,16 dengan standar deviasi 1,625. Berdasarkan tabel statistik deskriptif ini memberikan informasi bahwa ada perbedaan hasil belajar peserta didik sebelum dan setelah dilakukan penerapan metode pembelajaran Lattice.

\section{Pengujian Persyaratan Analisis Data}

Sebelum berlanjut pada pengujian uji-t maka dilakukan uji prasyarat data yang terdiri dari uji normalitas data dan uji homogenitas data. Uji normalitas data merupakan uji untuk mengukur apakah data yang didapatkan memiliki distribusi normal sehingga untuk menganalisis data dapat dipakai statistik parametrik (statistik inferensial). Dalam uji normalitas dilakukan sebanyak dua kali, yang pertama uji normalitas pada data hasil pretest dan uji yang kedua pada data hasil posttest.

Untuk uji normalitas aturan pengambilan keputusannya yaitu: jika p-value (nilai pada kolom sig. pada tabel tests of normality $)<\alpha$ maka $\mathrm{H}_{0}$ ditolak. Hipotesis untuk uji normalitas yaitu:

$$
\begin{aligned}
& \mathrm{H}_{0}=\text { Data berasal dari populasi yang berdistribusi normal } \\
& \mathrm{H}_{1}=\text { Data tidak berasal dari populasi yang berdistribusi normal }
\end{aligned}
$$

Tabel 7. Tes Normalitas Pretest dan Posttest

\begin{tabular}{lcccrrr}
\hline & \multicolumn{3}{c}{ Kolmogorov-Smirnov } & \multicolumn{3}{c}{ Shapiro-Wilk } \\
\cline { 2 - 8 } & Statistic & Df & Sig. & Statistic & Df & \multicolumn{1}{c}{ Sig. } \\
\hline Pretest & 0,159 & 25 & 0,102 & 0,934 & 25 & 0,108 \\
Postest & 0,177 & 25 & 0,041 & 0,945 & 25 & 0,194 \\
\hline a. Lilliefors Significance Correction & & & & & &
\end{tabular}

Dari tabel 7 di atas, diperoleh nilai Sig. (p-value) untuk uji normalitas dengan metode shapiro-wilk variabel pretest sebesar 0,108 (10,8\%) dan variabel posttest sebesar 0,194 (19,4\%). Artinya $p$-value $>\alpha$. Sehingga dapat disimpulkan $\mathrm{H}_{0}$ diterima. Artinya data berasal dari populasi yang berdistribusi normal. 
Uji homogenitas merupakan uji untuk mengetahui apakah dua variabel mempunyai hubungan yang homogen atau tidak secara signifikan. Uji ini biasanya digunakan sebagai uji prasyarat dalam analisis uji-t. Pada uji $\mathrm{F}$ antara hasil pretest dengan posttest diperoleh nilai $F_{\text {hitung }}=1,57$ dan nilai $F_{\text {tabel }}=1$,98. Karena nilai $F_{\text {hitung }}$ lebih kecil dari $F_{\text {tabel }}$ pada taraf signifikan 5\% sehingga disimpulkan data homogen.

\section{Pengujian Hipotesis}

Setelah uji normalitas dan uji homogenitas, peneliti melanjutkan ke analisis uji-t untuk mencari sebesar apa pengaruh yang ada antara variabel penerapan metode pembelajaran Lattice (X) terhadap variabel hasil belajar (Y), dengan menggunakan rumus sampel berpasangan. Untuk menguji hipotesis yang diajukan terbukti atau tidak, maka nilai $\mathrm{t}$ hitung dibandingkan dengan $t_{\text {tabel }}$ dengan taraf signifikan $5 \%$ dan pengujian dilakukan dengan menggunakan uji dua pihak.

Dalam penelitian ini hipotesis alternatif $\left(\mathrm{H}_{1}\right)$ yang berbunyi ada pengaruh metode pembelajaran Lattice terhadap hasil belajar belajar matematika peserta didik kelas VII SMPN 2 Bua dan hipotesis tandingannya adalah hipotesis nol $\left(\mathrm{H}_{0}\right)$ yang berbunyi tidak ada pengaruh metode pembelajaran Lattice terhadap hasil belajar belajar matematika peserta didik kelas VII SMPN 2 Bua. Dari hasil analisis data, diperoleh: nilai $t_{\text {hitung }}=4,705$ yang berarti variabel tersebut saling mempengaruhi, karena hasil $t$ hitung berada pada daerah penolakan Ho dan lebih besar dari $t_{\text {tabel }}=2,064$. Oleh karena $t_{\text {hitung }}$ lebih besar dari $t_{\text {tabel }}$ maka hipotesis nol $\left(\mathrm{H}_{0}\right)$ ditolak sehingga hipotesis alternatif $\left(\mathrm{H}_{1}\right)$ diterima. Artinya ada pengaruh penerapan metode pembelajaran Lattice terhadap hasil belajar matematika pada materi bilangan bulat peserta didik kelas VII SMPN 2 Bua.

Setelah dilakukan uji normalitas, homogenitas, dan uji hipotesis diperoleh hasil yang tidak sia-sia, karena adanya pengaruh penerapan metode pembelajaran Lattice terhadap hasil belajar matematika peserta didik. Hal ini dapat diketahui bahwa kemampuan awal peserta didik kurang baik, karena hasil tes peserta didik sebelum diberi perlakuan memiliki rata-rata hasil belajar yang rendah dibandingkan rata-rata hasil tes peserta didik setelah adanya perlakuan. Hal tersebut berdasarkan hasil perhitungan rata-rata nilai posttest 7,3 sedangkan untuk hasil rata-rata pretest 3,96. Hasil tersebut didukung oleh penelitian yang dilakukan oleh Zubaidah et al. (2015) menyebutkan bahwa terjadi peningkatan hasil belajar peserta didik dengan menggunakan metode pembelajaran Lattice. Sejalan juga dengan penelitian yang dilakukan oleh Khumairoh (2017) yang menyebutkan bahwa ada pengaruh penggunaan metode Lattice terhadap hasil belajar peserta didik pada materi operasi perkalian pecahan 
desimal. Selanjutnya hasil penelitian ini didukung oleh penelitian yang dilakukan oleh Solikin et al. (2019) bahwa pada tahap tes diagnostik peserta didik masih memiliki kemampuan berhitung yang lemah dan kurangnya pemahaman cara menyelesaikan operasi perkalian dengan cara bersusun, selanjutnya hasil treatment pertama mereka mampu memahami kinerja metode pembelajaran Lattice. Pada treatment ketiga sampel mampu membenahi kesalahan yang dilakukan pada treatment sebelumnya. Pada treatment terakhir sampel sudah mampu menyelesaikan soal secara mandiri. Selanjutnya hasil penelitian ini juga sejalan dengan penelitian yang dilakukan oleh Fatmala, Muzaki, dan Pujilestari (2018) yang menunjukkan pengaruh signifikan penerapan metode pembelajaran Lattice untuk mengatasi kesulitan menyelesaikan operasi perkalian.

Temuan lain dalam penelitian ini yang dapat menjadi pertimbangan adanya pengaruh penerapan metode pembelajaran Lattice yaitu masing-masing peserta didik mengalami peningkatan hasil belajar sebelum dan setelah penerapan metode pembelajaran Lattice, walaupun peningkatannya tidak cukup signifikan. Akan tetapi hal tersebut sudah menjadi bukti adanya pengaruh penerapan metode pembelajaran lattice terhadap hasil belajar matematika peserta didik kelas VII di SMP Negeri 2 Bua.

\section{SIMPULAN DAN SARAN}

Berdasarkan hasil penelitian dan pembahasan, maka dapat disimpulkan bahwa 1) Hasil belajar peserta didik sebelum diterapkan metode pembelajaran Lattice memiliki ratarata 3,96 dengan standar deviasinya adalah 1,79,2) Hasil belajar peserta didik setelah penerapan metode pembelajaran Lattice diperoleh rata-rata 7,16 dengan standar deviasi 1,62 dan 3) Terdapat pengaruh penerapan metode pembelajaran Lattice terhadap hasil belajar matematika pada materi operasi perkalian bilangan bulat peserta didik kelas VII SMPN 2 Bua. Jika dilihat dari peningkatan nilai posttest dari nilai pretest, sehingga dapat diketahui bahwa pembelajaran menggunakan metode pembelajaran Lattice hasil belajarnya lebih baik.

Berdasarkan kesimpulan yang peneliti peroleh, maka peneliti menyarankan agar guru menyadari bahwa keberhasilan belajar peserta didik tidak hanya karena dapat memahami konsep dan teori serta dapat mengaplikasikannya melainkan karena metode pembelajaran yang dipilih oleh guru. Metode pembelajaran Lattice ini dapat menjadi alternatif yang digunakan oleh guru dalam mengajarkan operasi perkalian bilangan bulat. 


\section{DAFTAR PUSTAKA}

Fatmala, F. W., Muzaki, A., \& Pujilestari. (2018). Pengaruh Penerapan Lattice Multiplication Method untuk Mengatasi Kesulitan Menyelesaikan Operasi Perkalian. Media Pendidikan Matematika Program Studi Pendidikan Matematika FPMIPA IKIP Mataram, 6(2) , 68-78.

Handojo, B. H. (2004). Math Magic. Jakarta: Kawan Pustaka.

Hapriani. (2018). Pengaruh Penggunaan Metode Lattice terhadap Hasil Belajar Siswa pada Mata Pelajaran Matematika Kelas IV MI Miftahul Ishlah Tembelok-Sandubaya. Skripsi. UIN Mataram. Retrieved from http://etheses.uinmataram.ac.id/1262/

Khumairoh, I. (2017). Pengaruh Penggunaan Metode Lattice terhadap Hasil Belajar Peserta Didik Kelas V SD Islam Hidayatullah pada Materi Operasi Perkalian Pecahan Desimal Mata Pelajaran Matematika Tahun Ajaran 2016/2017. Skripsi. Universitas Islam Negeri Walisongo Semarang. from http://eprints.walisongo.ac.id/7641/1/133911039.pdf

Kusumawati, A. D. A. (2010). Penerapan Pembelajaran Menggunakan Metode Kisi-kisi (Lattice Method) dengan Model Pembelajaran langsung pada Pokok Bahasan Perkalian untuk Meningkatkan Hasil Belajar Siswa Kelas V MINU Waru II. Skripsi yang Tidak Dipublikasikan. IAIN Sunan Ampel surabaya.

Mulyanto, K., Handoyo, E. D., \& Santoso, S. (2019). Perancangan Game Edukasi untuk Operasi Dasar Matematika dengan Penerapan Metode Lattice "Rancage Matematika". Jurnal Strategi, 1(2) , 362-373.

Musa, L. A. D. (2016). Level Berpikir Geometri Menurut Teori Van Hiele Berdasarkan Kemampuan Geometri dan Perbedaan Gender Siswa Kelas VII SMPN 8 Pare-Pare. Al-Khwarizmi: Jurnal Pendidikan Matematika dan Ilmu Pengetahuan Alam, 4(2), 103-116.

Solikin, N. K. R., Cipta, D. A. S., \& Anugraini, A. P. (2019). Penggunaan Metode Lattice dalam Mengatasi Rendahnya Kemampuan Berhitung Operasi Perkalian. Prismatika: Jurnal Pendidikan dan Riset Matematika, 2(1), 51-57.

Subana \& Sudrajat. (2005). Dasar-dasar Penelitian Ilmiah. Bandung: CV. Pustaka Setia.

Sugiyono. (2013). Metode Penelitian Pendekatan Kuantitatif, Kualitatif, dan R\&D. Bandung: Alfabeta.

Uskono, I. V., Djong, K. D., \& Leton, S. I. (2019). Penerapan Model Pembelajaran Matematika Relistik pada Pokok Bahasan Bilangan Bulat. Range: Jurnal Pendidikan Matematika, 1(2), 138-144.

Wardhani, S. (2010). Implikasi Karakteristik Matematika dalam Pencapaian Tujuan Mata Pelajaran Matematika di SMP/MTs. Yogyakarta: Departemen Pendidikan Nasional Direktorat Jenderal Peningkatan Mutu Pendidik dan Tenaga Kependidikan Pusat Pengembangan Dan Pemberdayaan Pendidik dan Tenaga Kependidikan (PPPPTK) Matematika.

Yudhautama, L., \& Ratu, N. (2019). Pengembangan Alper Silabu pada Materi Bilangan Bulat Kelas IV. Jurnal Review Pembelajaran Matematika, 4(1), 72-84. https://doi.org/10.15642/jrpm.2019.4.1.72-84

Zubaidah, Margiati, \& Kresnadi, H. (2015). Peningkatan Hasil Belajar Matematika dengan Metode Lattice di Kelas III Sekolah Dasar. Jurnal Pendidikan dan Pembelajaran Khatulistiwa, 4(1), 1-17 